\title{
Evaluation of Immunostimulatory and Antioxidant Activities of Ginger and Moringa Extracts Against Paracetamol Induced Hepatic Damage in Rats.
}

Hashem, M. A.; Mahmoud, E. A. and Ghada I. Abd El-Rahman

Clin. Pathol. Dept., Fac. Of Vet. Med., Zag. Univ.

\section{Abstract}

The present study was conducted to investigate the ameliorative effect of both Zingiber officinale and Moringa oleifera ethanolic extracts on rats intoxicated by paracetamol through some immunological and antioxidant studies.

One hundred and eighty apparently healthy male albino rats were divided into 12 equal groups, each of 15 rats. Gp. (1) kept as control, Gp. (2) was orally given paracetamol $(2 \mathrm{~g} / \mathrm{kg})$ for 4 weeks, Gp. (3) was orally given ginger ethanolic extract (200 $\mathrm{mg} / \mathrm{kg}$ ) for 4 weeks, Gp. (4) was orally given moringa ethanolic extract $(200 \mathrm{mg} / \mathrm{kg})$ for 4 weeks, Gp. (5) was orally given silymarin $(200 \mathrm{mg} / \mathrm{kg})$ for 4 weeks. Gps. $(6,7,8)$ (prophylaxis groups) were administered ginger, moringa ethanolic extracts or both extracts respectively for 2 weeks then paracetamol for another 2 weeks by the previous doses. Gps. $(9,10,11)$ were firstly given paracetamol for 2 weeks then the plant extracts for the following 2 weeks. Gp. (12) was orally given paracetamol for 2 weeks then silymarin for the other 2 weeks. Blood samples were collected at the end of the $2^{\text {nd }}$ and $4^{\text {th }}$ week of experiment. Liver, kidney and spleen specimens were collected and immediately fixed in $10 \%$ neutral buffered formalin for histopathological examination.

The results showed lymphopenia and granulocytosis in gp. (2) all over the experiment with increase phagocytic index only at the $2^{\text {nd }}$ week in addition to increase hepatic MDA and reduction in catalase levels compared to the normal control. The prophylactic groups $(6,7,8)$ manifested good amelioration in the fore mentioned parameters in comparison to treatment ones (912). It could be concluded that the natural plants are effective as a prophylaxis theraby against paracetamol toxicity not as a treatment ones. Combination of plant extracts with chemical drug (paracetamol) may give a new challenge in the face of diseases.

Key words: paracetamol over dose, ginger, moringa and hepatic damage. 


\section{Introduction}

Liver diseases are still a worldwide health problem. Considering the hazards of treatment failure such as drug resistance and heavy costs of therapy (Magda et al., 2011). Remediation of liver injuries by natural plants and herbs has been applied in India since ancient times and distributed all over the world by prime pharmaceuticals (Arpita et al., 2011). Some plants and herbs used today are valued for their antioxidant and hepato-protective effects as Zingiber officinale (ginger) and Moringa oleifera (moringa). Ginger has many medicinal effects that proved by many recent scientific researches such as antioxidant, hepatoprotective (Yemitan and Izegbu, 2006) and immunostimulatory effects (Zhou et al., 2006). Moringa oleivera is the most widely spread species of a monogeneric family Moringaceae (Anwar et al., 2007). Several active components as glucosinolates, isothiocyanates, thiocarbamates and flavonoids supported the antioxidant activity of Moringa oleifera (Santos et al., 2012). Hepatic damage caused by overdose or long use of paracetamol exist important practical troubles that may reach to about $40 \%$ of acute liver failure cases (Wallace, 2004).

The aim of the present work was to investigate the prophylactic and curative effects of both $Z$. officinale and $M$. oleifera extracts against paracetamol toxicity through evaluation of the immune response and antioxidant status of rats.

\section{Materials and methods}

\section{Materials \\ 1- Experimental animals:}

A total number of 180 apparently healthy adult male albino rats (100$150 \mathrm{~g}$ average body weight) were obtained from the laboratory animal housing, Faculty of Veterinary Medicine, Zagazig University. The animals were housed in metal cages under hygienic conditions. They were given balanced ration with water ad-libitum and observed for 7 days before starting of experiment.

\section{2- Plants:}

Ginger rhizomes were obtained from the local markets. M. oleifera leaves were obtained from herbalist. They used at a dose of $200 \mathrm{mg} / \mathrm{kg}$ b.wt orally according to Ajith et al. (2007) and Fakurazi et al. (2008) respectively.

\section{3- Drugs:}

Silymarin powder (Livamarin) was obtained from European Egyptian Pharm. IND. (Alexandria, Egypt). It used by the dose of $200 \mathrm{mg} / \mathrm{kg}$ b.wt orally for 4 weeks (Kanchanai and Sadiq, 2011). Acetaminophen (paracetamol) cetal was obtained from PHARCO pharmaceuticals (Alexandria, Egypt) and used at a dose of $2 \mathrm{~g} / \mathrm{kg}$ b.wt orally for 4 weeks (Eesha et al., 2011).

\section{Methods \\ Blood samples:}

At the end of the $2^{\text {nd }}$ and $4^{\text {th }}$ week of experiment, blood sample was collected from the retro-orbital 
venous plexus of each rat and divided into two parts. The $1^{\text {st }}$ part $(1 \mathrm{ml})$ was taken in clean EDTA tube for hematological studies (leukogram) (Coles, 1986), while the $2^{\text {nd }}$ one $(3 \mathrm{ml})$ was taken in heparinized tube for phagocytic assay.

Tissue specimens:

Samples from the liver, kidney and spleen were collected from all groups in $10 \%$ formalin for histopathological studies. Also, specimens of liver were taken and homogenized for measurement of MDA and CAT activities.

\section{Hematological techniques:}

\section{Leukogram:}

The total and differential leukocytic counts were carried out by using automatic cell counter (Feldman et al., 2000)

Evaluation of phagocytic activity $\&$ phagocytic index

This method is based on the uptake of C.albicans by monocytes over a certain period of time. Under the oil immersion lens of a light microscope, a total number of 100 phagocytic cells were counted randomly in about ten microscopic fields. The total number of phagocytes which ingested yeast cells was determined to calculate the percentage of phagocytosis and phagocytic index (Wilkinson, 1977)

Phagocytic (\%): is the number of monocytes ingesting Candida albicans.

Number of monocytes containing Candida albicans $\quad \chi 100$ Phagocytic index: is

Total number of counted monocytes

The number of C. albicans ingested by 100 monocytes.

Antioxidant studies:

Hepatic malondialdehyde (MDA) and catalase (CAT) activities were performed according to Ohkawa et al. (1979) and Aebi (1984) respectively using test kits of spectrum.

\section{Statistical analysis:}

The obtained data were statistically analyzed by F- test as stated by Tamhane and Dunlop (2000). Means at the same column followed by different letters were significantly different and the highest value was represented with the letter a. 
Experimental design (Table 1): One hundred and eighty (180) adult male rats were divided into 12 groups; each group contained 15 rats.

\begin{tabular}{|c|c|c|c|c|c|}
\hline \multirow[b]{2}{*}{ Groups } & \multicolumn{4}{|c|}{ Treatments (dose and duration) } & Sampling \\
\hline & $\begin{array}{c}\text { Paracetamol } \\
\text { (2g/kg b.wt } \\
\text { orally) }\end{array}$ & $\begin{array}{c}\text { Ginger } \\
\text { (200mg/kg b.wt } \\
\text { orally) } \\
\end{array}$ & $\begin{array}{c}\text { Moringa } \\
\text { (200mg/kg b.wt } \\
\text { orally) } \\
\end{array}$ & $\begin{array}{c}\text { Silymarin } \\
(200 \mathrm{mg} / \mathrm{kg} \\
\text { b.wt orally) }\end{array}$ & \multirow{13}{*}{ 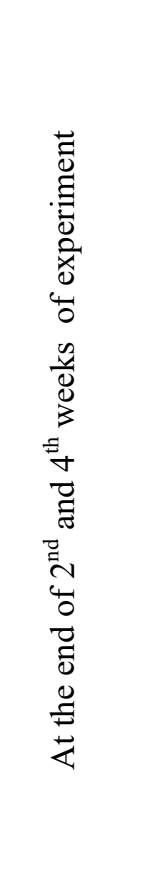 } \\
\hline 1 & - & - & - & - & \\
\hline 2 & For 4 weeks & - & - & - & \\
\hline 3 & - & For 4 weeks & - & - & \\
\hline 4 & - & - & For 4 weeks & - & \\
\hline 5 & - & - & - & For 4 weeks & \\
\hline 6 & \multirow{3}{*}{$\begin{array}{l}\text { For the last } \\
2 \text { weeks }\end{array}$} & $\begin{array}{c}\text { For the first } 2 \\
\text { wks }\end{array}$ & - & - & \\
\hline 7 & & - & $\begin{array}{c}\text { For the first } 2 \\
\text { wks }\end{array}$ & - & \\
\hline 8 & & $\begin{array}{c}\text { For the first } 2 \\
\text { wks }\end{array}$ & $\begin{array}{c}\text { For the first } 2 \\
\text { wks }\end{array}$ & - & \\
\hline 9 & \multirow{4}{*}{$\begin{array}{l}\text { For the first } \\
2 \text { weeks }\end{array}$} & $\begin{array}{c}\text { For the last } 2 \\
\text { wks }\end{array}$ & - & - & \\
\hline 10 & & - & $\begin{array}{c}\text { For the last } 2 \\
\text { wks }\end{array}$ & - & \\
\hline 11 & & $\begin{array}{c}\text { For the last } 2 \\
\text { wks }\end{array}$ & $\begin{array}{c}\text { For the last } 2 \\
\text { wks }\end{array}$ & - & \\
\hline 12 & & - & - & $\begin{array}{c}\text { For the last } 2 \\
\text { wks }\end{array}$ & \\
\hline
\end{tabular}

\section{RESULTS}

Regarding to the leukogram, Gp. (2) showed highly significant decrease in lymphocytic count with graulocytosis all over the experiment in addition, leukopenia observed only at the $4^{\text {th }}$ week of experiment in this group. These parameters statistically changed for better in plant prophylactic groups at the end of $4^{\text {th }}$ week of experiment with the best value in Gp. (8). While, only gps. $(11,12)$ showed slight improvement in leukogram picture compared to paracetamol treated group (Tables 2 and 3 ).
Moreover, highly significant increase in phagocytic index was observed in all groups with nonsignificant changes in monocytic count and phagocytic \% compared to normal control at the $2^{\text {nd }}$ week of experiment, while at the end of $4^{\text {th }}$ week, Gp. (8) showed highly significant increase in monocytic count and phagocytic \% and groups $(6,8,11)$ showed highly significant increase in phagocytic index compared to gp. (2), the highest value observed in gp. (8) (Tables 2 and 3).

Concerning the results of lipid peroxidation and antioxidant 
enzymes, hepatic MDA showed highly significant increase with reduction in catalase enzyme in paracetamol treated group (gp.2) at both periods of experiment compared to normal control. Groups
$(6,7,8)$ and gps (9-12) showed highly significant reduction in hepatic MDA with elevation in CAT activity compared to gp. (2) at the end of $4^{\text {th }}$ week of experiment (Table 4).

Table 2: Leukogram $\left(\chi 10^{3} / \mu l\right)$ and phagocytic activity of experimental groups (Mean values \pm S.E) at the $2^{\text {nd }}$ week of experiment.

\begin{tabular}{|c|c|c|c|c|c|c|}
\hline Periods & \multicolumn{6}{|c|}{2 weeks } \\
\hline Groups & TLC & Lymphocytes & Monocytes & Granulocytes & $\begin{array}{c}\text { Phagocytic } \\
\%\end{array}$ & $\begin{array}{l}\text { Phagocytic } \\
\text { index }\end{array}$ \\
\hline Gp.1 & $\begin{array}{c}10.07 \pm 0.48 \\
\text { b }\end{array}$ & $8.65 \pm 0.36 \mathrm{c}$ & $1.01 \pm 0.03$ & $0.44 \pm 0.09 \mathbf{b}$ & $82.4 \pm 0.40$ & $\begin{array}{c}2.98 \pm 0.06 \\
\text { d }\end{array}$ \\
\hline Gp.2 & $\begin{array}{c}14.50 \pm 1.19 \\
\mathbf{a}\end{array}$ & $4.05 \pm 0.37 \mathbf{d}$ & $0.95 \pm 0.04$ & $9.5 \pm 0.88 \mathbf{a}$ & $80.8 \pm 0.49$ & $4.82 \pm 0.04 \mathbf{a}$ \\
\hline Gp.3 & $\begin{array}{c}15.53 \pm 1.54 \\
\mathbf{a}\end{array}$ & $13.82 \pm 1.44 \mathbf{a b}$ & $0.98 \pm 0.06$ & $0.73 \pm 0.05 \mathbf{b}$ & $82.8 \pm 0.49$ & $\begin{array}{c}4.24 \pm 0.08 \\
\text { b }\end{array}$ \\
\hline Gp.4 & $\begin{array}{c}17.07 \pm 0.98 \\
\mathbf{a}\end{array}$ & $15.62 \pm 0.96 \mathbf{a}$ & $0.91 \pm 0.05$ & $0.54 \pm 0.04 \mathbf{b}$ & $81.6 \pm 0.93$ & $\begin{array}{c}4.34 \pm 0.14 \\
\text { b }\end{array}$ \\
\hline Gp.5 & $\begin{array}{c}13.43 \pm 1.18 \\
\mathbf{a b}\end{array}$ & $11.64 \pm 1.05 \mathbf{b}$ & $0.94 \pm 0.05$ & $0.85 \pm 0.03 \mathbf{b}$ & $83.6 \pm 0.40$ & $3.50 \pm 0.2 \mathrm{c}$ \\
\hline Gp.1 & $\begin{array}{c}10.07 \pm 0.48 \\
\text { b }\end{array}$ & $8.65 \pm 0.36 \mathbf{c}$ & $1.01 \pm 0.03$ & $0.44 \pm 0.09 \mathbf{b}$ & $82.4 \pm 0.40$ & $\begin{array}{c}2.98 \pm 0.06 \\
\text { d }\end{array}$ \\
\hline Gp.2 & $\begin{array}{c}14.50 \pm 1.19 \\
\text { c }\end{array}$ & $4.05 \pm 0.37 \mathbf{d}$ & $0.95 \pm 0.04$ & $9.5 \pm 0.88 \mathbf{a}$ & $80.8 \pm 0.49$ & $\begin{array}{c}4.82 \pm 0.04 \\
\text { b }\end{array}$ \\
\hline Gp.6 & $\begin{array}{c}15.60 \pm 0.71 \\
\mathbf{a b}\end{array}$ & $13.99 \pm 0.64 \mathbf{b}$ & $0.88 \pm 0.03$ & $0.73 \pm 0.03 \mathbf{b}$ & $82.4 \pm 0.75$ & $4.16 \pm 0.12 \mathrm{c}$ \\
\hline Gp.7 & $\begin{array}{c}16.67 \pm 1.06 \\
\mathbf{a b}\end{array}$ & $15.03 \pm 0.89 \mathbf{a b}$ & $1.04 \pm 0.08$ & $0.60 \pm 0.13 \mathbf{b}$ & $82.6 \pm 1.03$ & $4.02 \pm 0.04 \mathbf{c}$ \\
\hline Gp.8 & $\begin{array}{c}18.50 \pm 1.23 \\
\mathbf{a}\end{array}$ & $16.71 \pm 1.05 \mathbf{a}$ & $0.87 \pm 0.05$ & $0.93 \pm 0.14 \mathbf{b}$ & $83.2 \pm 0.49$ & $5.22 \pm 0.05 \mathbf{a}$ \\
\hline Gp.1 & $\begin{array}{c}10.07 \pm 0.48 \\
\text { b }\end{array}$ & $8.65 \pm 0.36 \mathbf{a}$ & $1.01 \pm 0.03$ & $0.44 \pm 0.09 \mathbf{b}$ & $82.4 \pm 0.40$ & $\begin{array}{c}2.98 \pm 0.06 \\
\text { d }\end{array}$ \\
\hline Gp.2 & $\begin{array}{c}14.50 \pm 1.19 \\
\mathbf{a}\end{array}$ & $4.05 \pm 0.37 \mathbf{c}$ & $0.95 \pm 0.04$ & $9.5 \pm 0.88 \mathbf{a}$ & $80.8 \pm 0.49$ & $\begin{array}{c}4.82 \pm 0.04 \\
\text { b }\end{array}$ \\
\hline Gp.9 & $\begin{array}{c}16.33 \pm 0.75 \\
\mathbf{a}\end{array}$ & $6.04 \pm 0.12 \mathbf{b}$ & $0.95 \pm 0.05$ & $9.34 \pm 0.63 \mathbf{a}$ & $84 \pm 0.63$ & $5.92 \pm 0.06 \mathbf{a}$ \\
\hline Gp.10 & $\begin{array}{c}15.27 \pm 0.74 \\
\mathbf{a}\end{array}$ & $4.79 \pm 0.48$ bc & $1.02 \pm 0.09$ & $9.46 \pm 0.25 \mathbf{a}$ & $81.2 \pm 1.02$ & $4.80 \pm 0.1 \mathbf{b}$ \\
\hline Gp.11 & $\begin{array}{c}16.12 \pm 1.28 \\
\mathbf{a}\end{array}$ & $3.92 \pm 0.87 \mathbf{c}$ & $1.04 \pm 0.11$ & $11.14 \pm 0.43 \mathbf{a}$ & $83 \pm 1.41$ & $4.34 \pm 0.22 \mathbf{c}$ \\
\hline Gp.12 & $\begin{array}{c}15.3 \pm 0.75 \\
\mathbf{a}\end{array}$ & $4.54 \pm 0.33$ bc & $0.95 \pm 0.06$ & $9.81 \pm 0.66 \mathbf{a}$ & $82.8 \pm 0.49$ & $4.34 \pm 0.07 \mathbf{c}$ \\
\hline F test & $* *$ & $* *$ & N.S & $* *$ & N.S & $* *$ \\
\hline
\end{tabular}

Means at the same column at the same period followed by different letters were significantly different and the highest value was represented with the letter a **: High significant at 0.01 probability 
Table 3. Leukogram $\left(\chi 10^{3} / \mu l\right)$ and phagocytic activity of experimental groups (Mean values \pm S.E) at the $4^{\text {th }}$ week of experiment.

\begin{tabular}{|c|c|c|c|c|c|c|}
\hline Periods & \multicolumn{6}{|c|}{4 weeks } \\
\hline Groups & TLC & Lymphocytes & Monocytes & Granulocytes & $\begin{array}{c}\text { Phagocytic } \\
\%\end{array}$ & $\begin{array}{l}\text { Phagocytic } \\
\text { index }\end{array}$ \\
\hline Gp.1 & $13.67 \pm 1.17 \mathbf{b}$ & $11.16 \pm 1.01 \mathbf{b}$ & $1.40 \pm 0.07 \mathbf{b}$ & $1.1 \pm 0.09 \mathrm{~d}$ & $79.2 \pm 0.49 \mathbf{c}$ & $3.0 \pm 0.05 \mathbf{c}$ \\
\hline Gp.2 & $8.10 \pm 0.21 \mathbf{c}$ & $1.91 \pm 0.13 b c$ & $1.08 \pm 0.09 \mathbf{b}$ & $5.12 \pm 0.09 \mathbf{a}$ & $80.4 \pm 0.93$ bc & $3.06 \pm 0.05 \mathbf{c}$ \\
\hline Gp.3 & $24.93 \pm 0.38 \mathbf{a}$ & $16.54 \pm 0.32 \mathbf{a}$ & $3.70 \pm 0.24 \mathbf{a}$ & $4.35 \pm 0.12 \mathbf{b}$ & $82 \pm 0.63 \mathbf{a b}$ & $4.40 \pm 0.07 \mathbf{b}$ \\
\hline Gp.4 & $25.93 \pm 1.94 \mathbf{a}$ & $17.55 \pm 0.96 \mathbf{a}$ & $4.30 \pm 0.92 \mathbf{a}$ & $4.09 \pm 0.09$ bc & $82.8 \pm 0.49 \mathbf{a}$ & $4.46 \pm 0.37 \mathbf{b}$ \\
\hline Gp.5 & $15.33 \pm 0.68 \mathbf{b}$ & $10.32 \pm 0.75 \mathbf{b}$ & $1.23 \pm 0.15 \mathbf{b}$ & $3.89 \pm 0.07 \mathbf{c}$ & $79 \pm 0.71 \mathbf{c}$ & $5.06 \pm 0.05 \mathbf{a}$ \\
\hline Gp.1 & $13.67 \pm 1.17 \mathbf{a}$ & $11.16 \pm 1.01 \mathbf{a}$ & $1.40 \pm 0.07 \mathbf{b}$ & $1.1 \pm 0.09 \mathrm{~d}$ & $79.2 \pm 0.49 \mathbf{b}$ & $3.0 \pm 0.05 \mathbf{c}$ \\
\hline Gp.2 & $8.10 \pm 0.21 \mathbf{b}$ & $1.91 \pm 0.13 \mathbf{c}$ & $1.08 \pm 0.09 \mathbf{b}$ & $5.12 \pm 0.09 \mathbf{a}$ & $80.4 \pm 0.93 \mathbf{b}$ & $3.06 \pm 0.05 \mathbf{c}$ \\
\hline Gp.6 & $12.50 \pm 0.38 \mathbf{a}$ & $8.18 \pm 0.14 \mathbf{b}$ & $1.18 \pm 0.09 \mathbf{b}$ & $3.13 \pm 0.15$ bc & $80 \pm 0.63 \mathbf{b}$ & $3.54 \pm 0.09 \mathbf{b}$ \\
\hline Gp.7 & $13.19 \pm 1.20 \mathbf{a}$ & $8.67 \pm 1.04$ b & $1.16 \pm 0.05 \mathbf{b}$ & $3.36 \pm 0.21 \mathbf{b}$ & $79.2 \pm 0.49 \mathbf{b}$ & $3.32 \pm 0.11 \mathbf{b c}$ \\
\hline Gp.8 & $14.63 \pm 0.87 \mathbf{a}$ & $9.77 \pm 0.59 \mathbf{a b}$ & $2.13 \pm 0.18 \mathbf{a}$ & $2.74 \pm 0.29 \mathbf{c}$ & $84.8 \pm 0.49 \mathbf{a}$ & $4.80 \pm 0.21 \mathbf{a}$ \\
\hline Gp.1 & $13.67 \pm 1.17 \mathbf{a}$ & $11.16 \pm 1.01 \mathrm{a}$ & $1.40 \pm 0.07 \mathbf{a b}$ & $1.1 \pm 0.09 \mathrm{~d}$ & $79.2 \pm 0.49 \mathbf{a b}$ & $3.0 \pm 0.05$ bcd \\
\hline Gp.2 & $8.10 \pm 0.21 \mathbf{d}$ & $1.91 \pm 0.13 \mathbf{d}$ & $1.08 \pm 0.09 \mathbf{b}$ & $5.12 \pm 0.09 \mathbf{a}$ & $80.4 \pm 0.93 \mathbf{a b}$ & $3.06 \pm 0.05$ bc \\
\hline Gp.9 & $9.90 \pm 1.07 \mathbf{c d}$ & $4.51 \pm 0.59 \mathbf{c}$ & $1.99 \pm 0.35 \mathbf{a}$ & $3.39 \pm 0.26 \mathbf{c}$ & $80.2 \pm 0.66 \mathbf{a b}$ & $3.18 \pm 0.04 \mathbf{a b}$ \\
\hline Gp.10 & $10.40 \pm 0.72 \mathbf{b c d}$ & $4.31 \pm 0.41 \mathbf{c}$ & $1.52 \pm 0.35 \mathbf{a b}$ & $4.57 \pm 0.12 \mathbf{a b}$ & $79 \pm 0.71 \mathbf{a b}$ & $2.8 \pm 0.1 \mathbf{d}$ \\
\hline Gp.11 & $11.47 \pm 0.93 \mathbf{a b c}$ & $5.94 \pm 0.13$ bc & $1.65 \pm 0.34 \mathbf{a b}$ & $3.87 \pm 0.49$ bc & $81.4 \pm 0.69 \mathbf{a}$ & $3.38 \pm 0.11 \mathbf{a}$ \\
\hline Gp.12 & $13.03 \pm 1.12 \mathbf{a b}$ & $7.0 \pm 0.61 \mathbf{b}$ & $2.15 \pm 0.26 \mathbf{a}$ & $3.88 \pm 0.31$ bc & $78.2 \pm 1.07 \mathbf{b}$ & $2.90 \pm 0.1 \mathrm{~cd}$ \\
\hline$F$ test & $* *$ & $* *$ & $* *$ & $* *$ & $* *$ & $* *$ \\
\hline
\end{tabular}

Means at the same column at the same period followed by different letters were significantly different and the highest value was represented with the letter a **: High significant at 0.01 probability 
Table 4: Hepatic catalase and MDA activities of experimental groups (Mean values \pm S.E) at the $2^{\text {nd }}$ and $4^{\text {th }}$ week of experiment.

\begin{tabular}{|c|c|c|c|c|}
\hline Periods & \multicolumn{2}{|c|}{2 weeks } & \multicolumn{2}{|c|}{4 weeks } \\
\hline Groups & $\begin{array}{c}\text { CAT } \\
\mathbf{U} / \mathbf{g}\end{array}$ & $\begin{array}{c}\text { MDA } \\
\text { Nmol/g }\end{array}$ & $\begin{array}{c}\text { CAT } \\
\text { U/g }\end{array}$ & $\begin{array}{c}\text { MDA } \\
\text { Nmol/g }\end{array}$ \\
\hline Gp.1 & $1.49 \pm 0.02 \mathbf{b}$ & $26.91 \pm 0.78 \mathbf{b}$ & $1.55 \pm 0.02 \mathrm{c}$ & $25.90 \pm 0.67 \mathbf{b}$ \\
\hline Gp.2 & $1.13 \pm 0.02 \mathbf{c}$ & $69.15 \pm 2.16 \mathbf{a}$ & $1.06 \pm 0.01 \mathrm{~d}$ & $75.39 \pm 1.79 \mathbf{a}$ \\
\hline Gp.3 & $1.94 \pm 0.008 \mathbf{a}$ & $16.68 \pm 0.27 \mathbf{c}$ & $2.40 \pm 0.06 \mathbf{a b}$ & $14.95 \pm 0.50 \mathbf{c}$ \\
\hline Gp.4 & $1.88 \pm 0.01 \mathbf{a}$ & $15.96 \pm 0.86 \mathbf{c}$ & $2.48 \pm 0.06 \mathbf{a}$ & $14.19 \pm 0.74 \mathbf{c}$ \\
\hline Gp.5 & $1.91 \pm 0.02 \mathbf{a}$ & $18.08 \pm 1.16 \mathbf{c}$ & $2.32 \pm 0.02 \mathbf{b}$ & $16.45 \pm 0.45 \mathbf{c}$ \\
\hline F test & $* *$ & $* *$ & $* *$ & $* *$ \\
\hline Gp.1 & $1.49 \pm 0.02 \mathbf{c}$ & $26.91 \pm 0.78 \mathbf{b}$ & $1.55 \pm 0.02 \mathbf{b}$ & $25.90 \pm 0.67 \mathbf{c}$ \\
\hline Gp.2 & $1.13 \pm 0.02 \mathbf{d}$ & $69.15 \pm 2.16 \mathbf{a}$ & $1.06 \pm 0.01 \mathrm{c}$ & $75.39 \pm 1.79 \mathbf{a}$ \\
\hline Gp.6 & $1.93 \pm 0.02 \mathbf{a b}$ & $14.42 \pm 1.37 \mathrm{c}$ & $1.79 \pm 0.02 \mathbf{a}$ & $31.09 \pm 1.26 \mathbf{b}$ \\
\hline Gp.7 & $1.85 \pm 0.03 \mathbf{b}$ & $18.29 \pm 1.22 \mathbf{c}$ & $1.76 \pm 0.02 \mathbf{a}$ & $33.0 \pm 1.97 \mathbf{b}$ \\
\hline Gp.8 & $1.96 \pm 0.03 \mathbf{a}$ & $15.15 \pm 1.23 \mathbf{c}$ & $1.82 \pm 0.02 \mathrm{a}$ & $30.13 \pm 1.04 \mathbf{b c}$ \\
\hline F test & $* *$ & $* *$ & $* *$ & $* *$ \\
\hline Gp.1 & $1.49 \pm 0.02 \mathbf{a}$ & $26.91 \pm 0.78 \mathbf{c}$ & $1.55 \pm 0.02 \mathrm{a}$ & $25.90 \pm 0.67 \mathbf{d}$ \\
\hline Gp.2 & $1.13 \pm 0.02 \mathbf{c}$ & $69.15 \pm 2.16 \mathbf{a}$ & $1.06 \pm 0.01 \mathrm{~d}$ & $75.39 \pm 1.79 \mathbf{a}$ \\
\hline Gp.9 & $1.10 \pm 0.01 \mathbf{c}$ & $67.71 \pm 1.76 \mathbf{a b}$ & $1.39 \pm 0.01 \mathrm{c}$ & $60.37 \pm 1.29 \mathbf{b}$ \\
\hline Gp.10 & $1.18 \pm 0.008 \mathbf{b}$ & $70.63 \pm 1.51 \mathbf{a}$ & $1.42 \pm 0.01 \mathrm{c}$ & $62.6 \pm 1.81 \mathbf{b}$ \\
\hline Gp.11 & $1.17 \pm 0.02 \mathbf{b c}$ & $62.43 \pm 2.39 \mathbf{b}$ & $1.50 \pm 0.008 \mathbf{b}$ & $55.07 \pm 1.05 \mathrm{c}$ \\
\hline Gp.12 & $1.14 \pm 0.02 \mathbf{b c}$ & $65.24 \pm 0.85 \mathbf{a b}$ & $1.47 \pm 0.01 \mathbf{b}$ & $53.86 \pm 0.96 \mathbf{c}$ \\
\hline F test & $* *$ & $* *$ & $* *$ & $* *$ \\
\hline
\end{tabular}

Means at the same column at the same period followed by different letters were significantly different and the highest value was represented with the letter a

$* *$ : High significant at 0.01 probability 


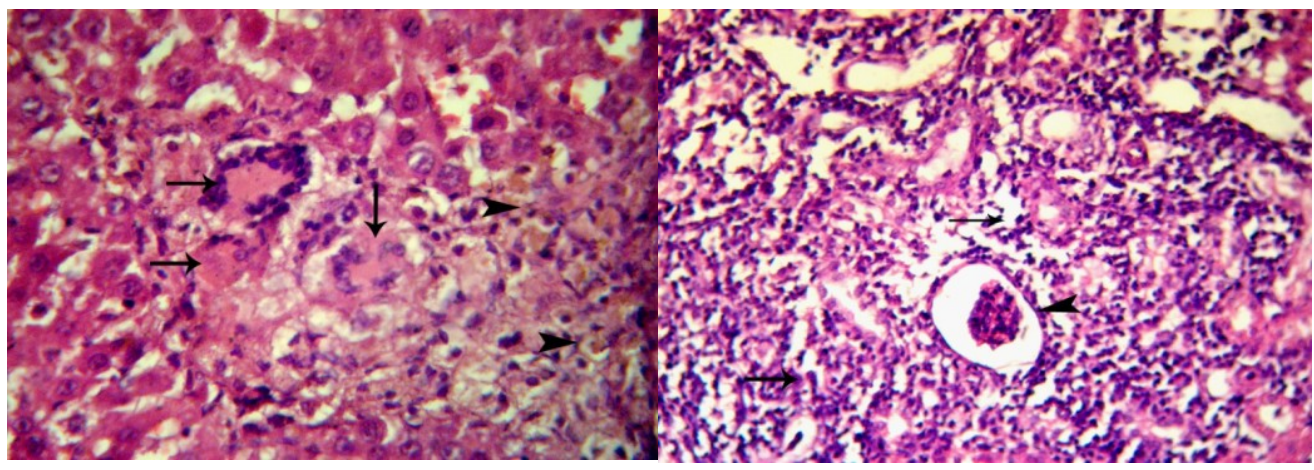

Fig. (1) : Liver of Gp.(2), showing extensive necrosis surrounded with granulomatous reaction of giant cells (arrows) besides cholestasis of brown pigments (arrowheads) ( $H \& E x 400)$.

Fig. (2): Kidney of Gp.(2), showing extensive necrosis and aggregations of inflammatory cells replacing the renal tissue (arrows) besides shrunken glomerular tuft (arrowhead) ( $H \& E x 400)$.
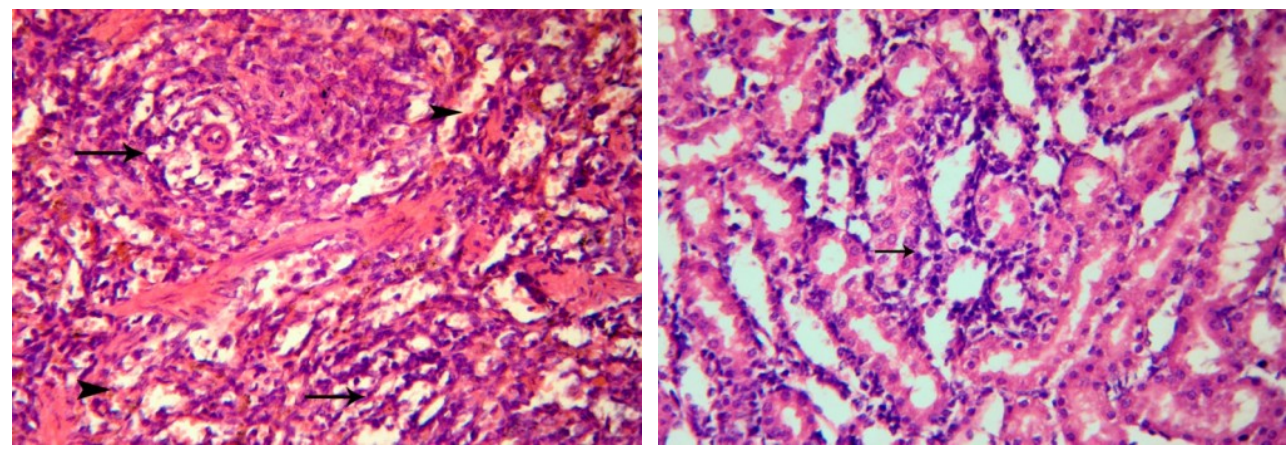

Fig. (3): Spleen of Gp.(2), showing necrosis and depletion of the lymphoid cells in the white pulp (arrow) and increased the fibrous tissue in the red pulp (arrow head) ( $H \& E \times 400)$.

Fig. (4): Kidney of Gp. (6), showing few lymphocytes infiltrations among the renal tubules (arrow) ( $H \& E x 400)$.
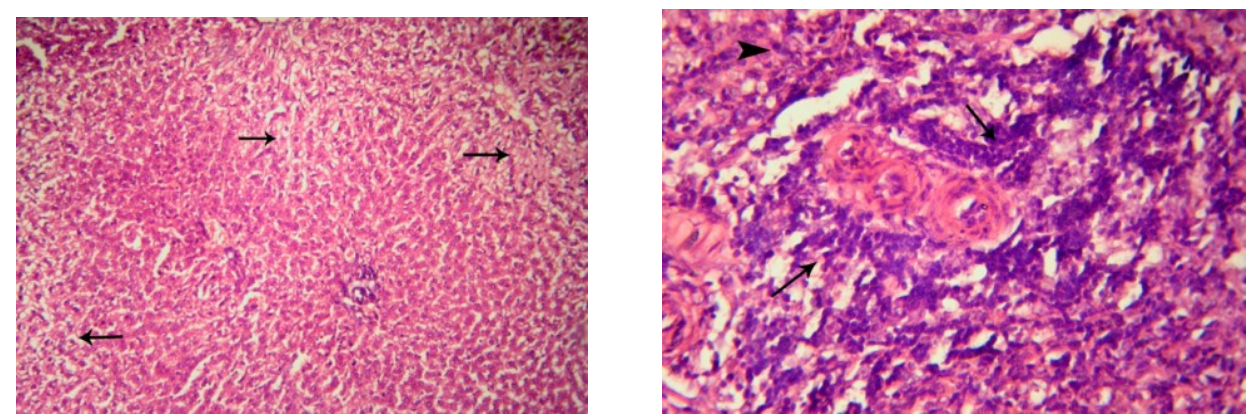

Fig. (5): Liver of Gp. (8), showing normal hepatic tissue with mild hydropic degeneration (arrows). (H\& Ex 150). 
Fig. (6): Spleen of Gp. (8), showing activation of the lymphoid cells in the white pulp with increased the mitosis (arrow and arrow head) ( $H \& E x 400)$.
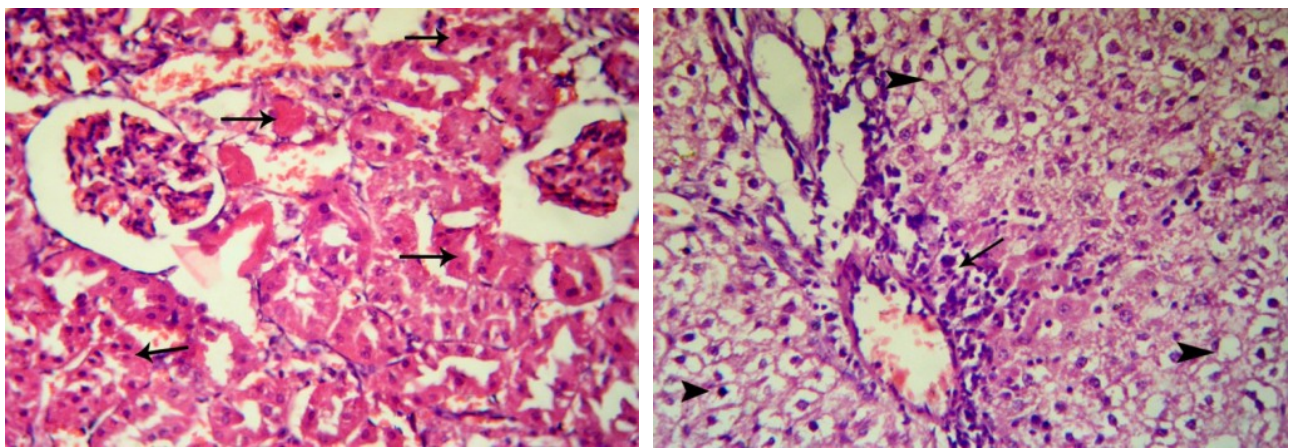

Fig.(7): Kidney of Gp. (10), showing coagulative necrosis in renal tubular epithelia (arrows) ( $H \& E x 400)$.

Fig.(8): Liver of $G p$. (11), showing inflammed portal area with congested blood vessels and lymphocytes infiltrations (arrow) and hydropic degeneration (arrowheads) ( $H \& E x 400)$.

\section{Discussion}

The present study demonstrates granulocytosis with lymphopenia in paracetamol treated group at both periods of experiment that might be due to the stress condition coupled with inflammatory changes in the body tissue responsible for phagocytosis of toxic substances (Bhaumik and sharma, 2002). Granulocytosis may be due to neutrophilia that related to tissue destruction caused by toxic metabolite of paracetamol (NAPQI). Toxic chemicals and drug may result in tissue destruction with increasing the number of circulating neutrophils (Coles, 1974). Lymphopenia may be attributed to the immunosuppressive effect of paracetamol with necrosis of lymphoid tissues (Young et al., 1975) or could be due to the migration of lymphocytes to site of damaged tissue as a part of defensive mechanism of the immune system. Our results coincided with those of Ahur et al. (2013) who indicated that oral administration of paracetamol at $2 \mathrm{~g} / \mathrm{kg}$ b.wt to rats showed significant decrease in total leukocytic and lymphocytic counts with neutrophilia as compared to normal control. Furthermore, leukopenia observed in this group at the end of $4^{\text {th }}$ weeks may be due to the cumulative chemotoxic effect of paracetamol toxic metabolite on the lymphoid organs. This result correlates with the histopathological findings of spleen in figure (3). Similar findings were reported by Senthilkumar et al. (2014) who observed reduction in total leukocytic count of wistar rats received $2 \mathrm{~g}$ of paracetamol $/ \mathrm{kg}$ b .wt for 14 days compared to control 
group. Complement to the above, increase in the phagocytic index in gp. (2) at the end of $2^{\text {nd }}$ week only, explaining the function of monocytes as phagocytic cell against any foreign substances and cellular debris that result from tissue necrosis caused by paracetamol toxicity. Our results are in agreement with Gordon and Taylor (2005) who reported that monocytes and tissue macrophage cooperate in the phagocytosis of pathogens and removal of damaged tissue by means of proteolytic digesion.

Prophylactic groups (6-8) showed significant improvement in leukogram manifested by leukocytosis and lymphocytosis with granulocytopenia compared to gp. (2) at the end of $4^{\text {th }}$ week that indicate the effectiveness of both ginger and moringa extracts as prophylactic agents against paracetamol toxicity and their ability to alleviate the stress condition applied on rats. It was found that $M$. oleifera extracts play a plausible role in enhancing the immunity, may be due to the vitamins and minerals such as arginine and vitamin $\mathrm{C}$ content in this plant (Banji et al., 2012). Also the presence of variety of flavonoids with antioxidant activity in $M$. oleifera is responsible for improvement of blood picture (Kaviarsan et al., 2004). Similar findings as improvement in the blood parameters and total leukocytic count were reported in rats prophylactic with mixtures of different plants (Roselle, Moringa, Ginger and Ugwu) for 180 days before exposure to cement dust (Yahaya et al., 2012)

Plant treated groups did not show any enhancement in leukogram except gp. (11) that might be due to the synergistic beneficial effect of $Z$. officinale and $M$. oleifera together. This partially agree with the results presented by Osman et al. (2012) and Tende et al. (2012) who recorded non-significant changes in total and differential leukocytic count of normal rats administered daily with moringa and ginger extracts respectively for nearly 4 weeks. Silymarin treatment (gp.12) clarified some degree of amelioration as the silymarin is a potent protein inducer via stimulation of RNA and DNA synthesis which is necessary for regeneration after toxic and inflammatory insults (Machicao and Sonnenbichler ,1977)

Increase in hepatic MDA concentration with decrement in catalase level in paracetamol treated group may be attributed to over production of free radicals and reactive oxygen species during paracetamol metabolism that leads to exhaustion of natural body antioxidant system and enhanced lipid peroxidation. Covalent binding of NAPQI, an oxidative product of paracetamol to sulphydryl group of protein cause rapid depletion of intracellular GSH resulting in cell necrosis and lipid peroxidation 
(Jollow et al., 1974). This is in agreement with Yanpallewar et al. (2002) who indicated that administration of paracetamol at $2 \mathrm{~g} / \mathrm{kg}$ for 7 days caused significant increase in MDA level.

Treatment with plant extracts abrogated the paracetamol induced decrease in catalase activity and elevation of lipid peroxidation marker. This suggests the ability of their antioxidant constituents to break lipoperoxidation chain reaction and facilitate the removal of reactive oxygen species generated by paracetamol over dose. Our results harmonize with the preceding findings of (Hamid et al., 2011 and Fakurazi et al., 2012) who mentioned that administration of ethyl acetate extract of Zingiber Zerumbe and M.oleifera hydroethanolic extract at doses of 200 and $400 \mathrm{mg} / \mathrm{kg}$ protected the rats from paracetamol hepatotoxicity by inhibition of liver MDA elevation and restoring the level of antioxidant enzymes (CAT and SOD).

It can be concluded that, Combination of two plants as ginger and moringa may provide a novel therapeutic strategy against paracetamol induced hepatic damage better than each alone as demonstrated by enhancing the immune status and antioxidant defense mechanism of rats.

\section{References}

Aebi (1984): Catalase in vitro. Meth Enzymol., 105:121-130.
Ahur V M, Adenkola Y A, Saganuwan $\mathbf{S} A$ and Ikye-Tor $J$ T (2013): Ameliorative properties of aqueous extract of Ficus thonningii on erythrocyte osmotic fragility induced by acetaminophen in Rattus norvegicus. Veterinary Research Forum, 4 (4): 207 - 212.

Ajith T A, Nivitha $V$ and Usha $S$ (2007): Zingiber officinale Roscoe alone and in combination with atocopherol protect the cisplatininduced acute renal failure. Food and Chemical Toxicology, 45: 921927.

Anwar F, Latif S, Ashraf $M$ and Gilani A H (2007): Moringa oleivera: a food plant with multiple medicinal uses. Phytother. Res., 21:17-25.

Arpita D, Prita $M$ and Panjal C (2011): Hepatotoxicity and hepatoprotectism herbs: Herbal remedies. International Journal of Research in Ayurveda \&Pharmacy, 2(4): 1073-1078.

Banji O J F, Banji D and Kavitha R (2012): Immunomodulatory effects of alcoholic and hydroalcoholic extracts of Moringa Oleivera lam leaves. Indian Journal of Experimental Biology, 50: 270276.

Bhaumik A and Sharma M C (2002): Therapeutic Efficacy of Liv.52 in Paracetamol induced Hepatopathy in Rabbits. Indian Journal Veterinary Research, 11 (1): 8-17.

Coles E H (1974):" Veterinary Clinical Pathology" 2nd Ed., W. B. 
Saunders Company, Philadelphia, London, Toronto, pp.77-83.

Coles E H (1986):" Veterinary Clinical Pathology" 4th Ed., W. B. Saunders Company, West Washington square, Philadelphia, Toronto.

Eesha B R, Mohanbabu A V, Meena K K, Sarath b, Vijay M , Lalit $M$ and Rajput $R$ (2011): Hepatoprotective activity of Terminalia paniculata against paracetamol induced hepatocellular damage in Wistar albino rats. Asian Pacific Journal of Tropical Medicine, 466-469.

Fakurazi S, Hairuszah I and Nanthini U (2008): Moringa oleivera prevents acetaminophen induced liver injury through restoration of glutathione level. Food. Chem. Toxicol., 46(8): 26112615.

Fakurazi S, Sharifudin S A and Arulselvan P (2012): Moringa oleivera hydroethanolic extracts effectively alleviate acetaminopheninduced hepatotoxicity in experimental rats through their antioxidant nature. Molecules, 17(7): 8334-8350.

Feldman BF, Zinki JG and Jain VC (2000): Schalm's Veterinary Hematology. 5th Ed., Lippincott Williams and Wilkins, Canada.

Gorden S and Taylor P R (2005): Monocyte and macrophage heterogeneity. Nature Reviews Immunology, 5 (12): 953-964.

Hamid A, Budin S B, Mohamed R A P, Abd Manaf N, Yuhana N $Y$, Husain $K$, Abd Hamid $Z$ and
Mohamed J (2011): Role of oxidative stress in the protective effects of Zingiber Zerumbet Smith ethyl acetate extract against paracetamol-induced hepatotoxicity in sprague-Dawley rats. Australian Journal of Basic and Applied Sciences, 5(8): 1519-1525.

Jollow D, Thorgeirsso S, Potter $W$ and Hashimoto $M$ (1974): Acetaminophen-induced hepatic necrosis. Metabolic disposition of toxic and nontoxic doses of acetaminophen. Pharmacology, 12: 251-271.

Kanchanai N and Sadiq A M (2011): Hepatoprotective effect of Plumbago Zeylanica on paracetamol induced liver toxicity in rats. International Journal of Pharmacy and Pharmaceutical Sciences, 3(1): 151-154.

Kaviarsan S, Vijayalakshmi $K$ and Anuradha C V (2004): Polyphenol-rich extract of Fenugreek seeds protect erythrocytes from oxidative damage. Plant Foods for Human Nutrition, 59: 143-147.

Machicao $\mathbf{F}$ and Sonnenbichler $\mathbf{J}$ (1977): Mechanism of the stimulation of RNA synthesis in rat liver nuclei by silybin. Hoppe Seylers Z Physiol. Chem., 358: 141-147.

Magda $K$ E, Germine $M \quad H$ and Rasha M A (2011): The synergistic hepatoprotective effect of curcumin and ginger against carbon tetrachloride induced liver fibrosis in rats. Australian Journal of Basic 
and Applied Sciences, 5(9): 19621971.

Ohkawa H, Ohishi I and Yagi E (1979): Assay for lipid peroxides in animal tissues by thiobarbitturic acid reaction. Anal. Biochem., 95:351-358.

Osman H M, Shayoub $M$ E and Babiker E M (2012): The effect of Moringa oleivera leaves on blood Parameters and body Weights of albino rats and rabbits. Jordan Journal of Biological Sciences, 5(3): 147-150.

Santos a F, Argolo a C, Paiva P M and Coelho $L \quad C$ (2012): Antioxidant activity of Moringa Oleifera tissue extracts. Phytotherapy Resarch, 26(9):13661370.

Senthilkumar R, Chandran $\mathbf{R}$ and Parimelazhagan $T$ (2014): Hepatoprotective effect of Rhodiola imbricate rhizome against paracetamol-induced liver toxicity in rats. Saudi Journal of Biological Sciences, 21: 409-416.

Tamhane AC and Dunlop DD (2000): Statistics and Data Analysis from Elementary to Intermediate. Upper Saddle River. USA.

Tende J A, Olorunshola K V, Mohammed A, Adelaiye A B and Eze E D (2012): Some Biochemical and Hematological Effects of Garlic (Allium sativum) and Ginger (Zingiber officiale) extracts in rats. Journal of Science, 2(2):121-126. Wallace J L (2004): Acetaminophen hepatotoxicity: NO to the rescue. British Journal of Pharmacology, 143:1-2.

Wilkinson P C (1977): Techniques in Clinical Immunology. Edited by Thompson RA. Blackwell Scientific Publications, Oxford, pp. 201-218, USA.

Yahaya $\mathbf{T}$, Okpuzor $J$ and Ajayi T (2012): The Prophylactic efficacy of Roselle [H. sabdariffa], Moringa [Moringa oleivera], Ginger [Z. officinale] and Ugwu [T. occidentalis] on the hematology and serum protein of albino rats [Rattus norvegicus] exposed to cement dust. Research Journal of Medicinal Plant, 6 (2): 189-196.

Yanpallewar et al. (2002) Yanpallewar S U, Sen S, Tapas S, Kumar M, Raju S S and Acharya S B (2002): Effect of Azadirachta indica on paracetamol-induced hepatic damage in albino rats. Phytomedicine, 9: 391-396.

Yemitan O K and Izegbu M C (2006): Protective effects of Zingiber officinale (Zingiberaceae) against carbon tetrachloride and acetaminophen-induced

hepatotoxicity in rats. Phytother. Res., 20: 997-1002.

Young D S, Prestaner $L C$ and Gibbermann V (1975): Effects of drugs on clinical laboratory tests. Clin. Chem., 21 (5): 1-431.

Zhou H, Deng $Y$ and Xie $Q$ (2006): The modulatory effects of the volatile oil of ginger on the cellular immune response in vitro and in vivo in mice. Journal of Ethnopharmacology, 105: 301-305. 


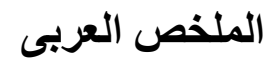

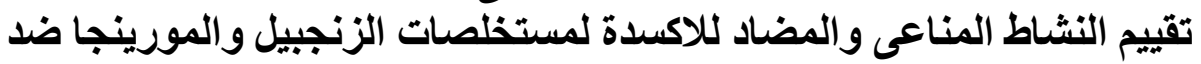

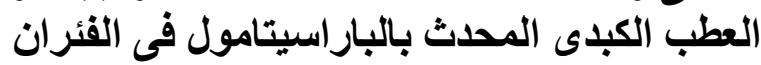

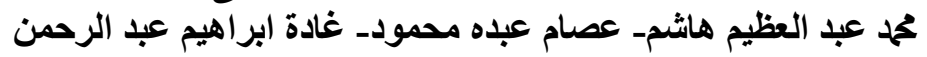

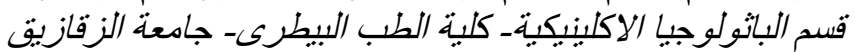

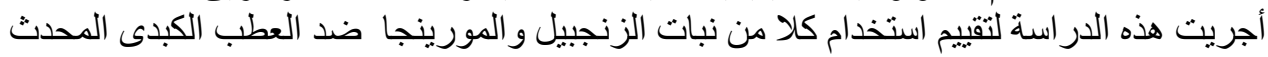

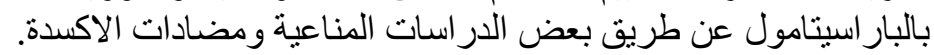

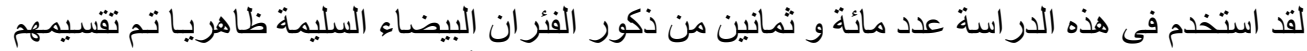

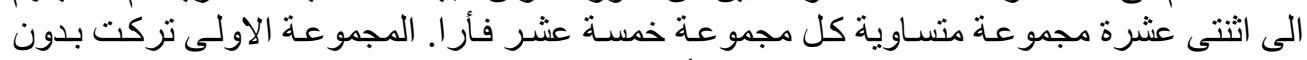

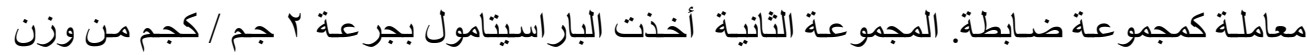

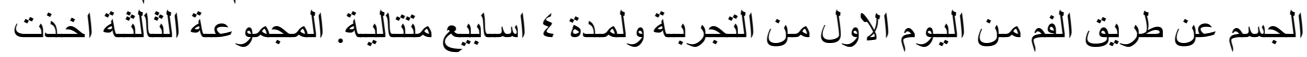

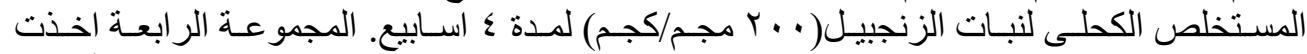

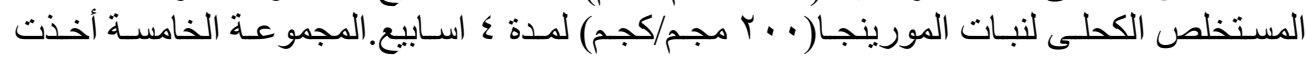

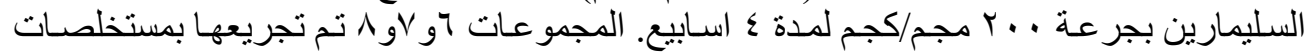

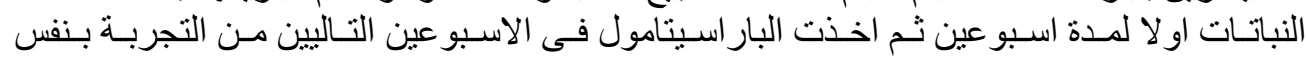

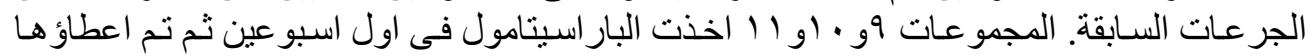

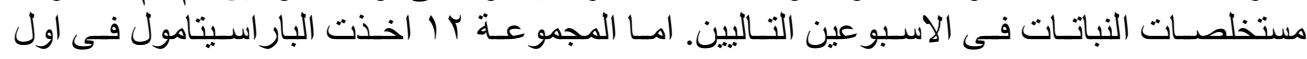

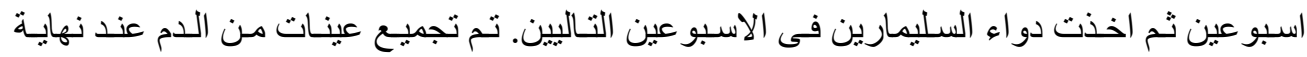

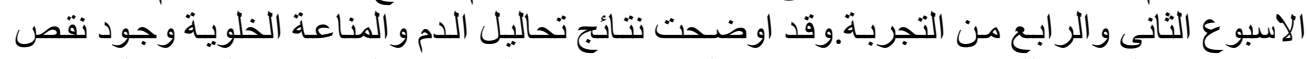

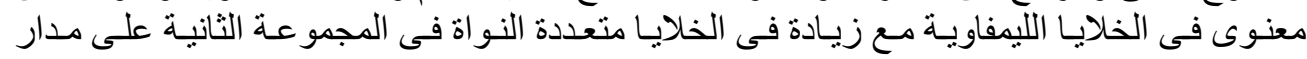

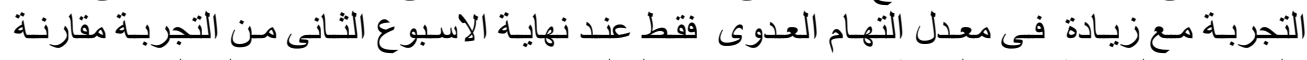

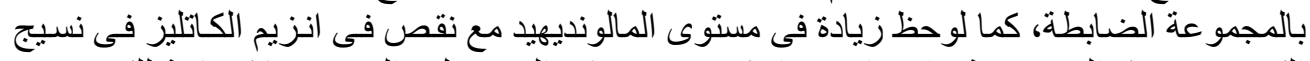

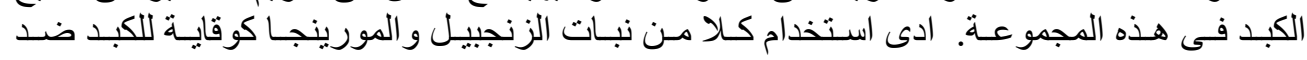

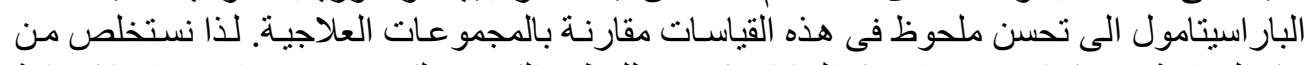

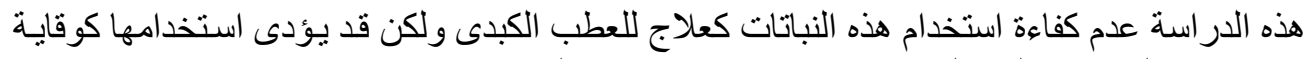

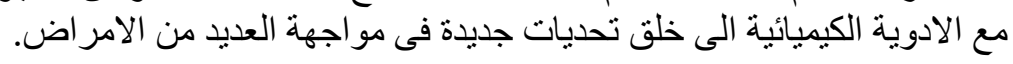

